\title{
The influence of sex on the prognostic value of body mass index in non-metastasis renal cell carcinoma
}

\author{
Yangqin Zheng ${ }^{1} *$ \\ Lianmin $\mathrm{Bao}^{2, *}$ \\ Jingfeng $\mathrm{Chen}^{3, *}$ \\ Yue $\mathrm{Pan}^{4}$ \\ Qinquan Wang ${ }^{4}$ \\ Lianguo Chen ${ }^{5}$ \\ Xiaomin $\mathrm{Gao}^{6}$
}

'Department of Hematology, The Third Clinical Institute Affiliated to Wenzhou Medical University, People's Hospital of Wenzhou, Wenzhou, Zhejiang 325006 , People's Republic of China; ${ }^{2}$ Department of Respiratory, Rui'an People's Hospital, The Third Affiliated Hospital of Wenzhou Medical University, Wenzhou, Zhejiang 325200, People's Republic of China; ${ }^{3}$ Department of Anorectal Surgery, The Sixth Affiliated Hospital of Wenzhou Medical University, Lishui People's Hospital, Lishui, Zhejiang 323000, People's Republic of China; ${ }^{4}$ Department of Urology, The First Affiliated Hospital of Wenzhou Medical University, Wenzhou, Zhejiang 325006, People's Republic of China; ${ }^{5}$ Department of Clinical Pharmacy, Wenzhou People's Hospital \& The Third Clinical Institute Affiliated to Wenzhou Medical University, Wenzhou, Zhejiang 325000, People's Republic of China; ' ${ }^{6}$ Department of Urology, Changhai Hospital, Second Military Medical University, Shanghai 200433, People's Republic of China

*These authors contributed equally to this work

Correspondence: Xiaomin Gao

Department of Urology, Changhai

Hospital, Second Military Medical

University, 168 Changhai Road, Yangpu

District, Shanghai 200433, People's

Republic of China

Tel +86 213 II6 IIII

Fax +86 216 5492727

Email doctorgaoxiaomin@163.com

Lianguo Chen

Department of Clinical Pharmacy,

Wenzhou People's Hospital and The

Third Clinical Institute Affiliated to

Wenzhou Medical University, Wenzhou,

Zhejiang 325000, People's Republic of

China

Tel +8657788059166

Fax +86 57788883131

Email lianguochen@I26.com
This article was published in the following Dove Press journal:

Cancer Management and Research

Purpose: The prognostic value of obesity in patients with renal cell carcinoma (RCC) remains controversial. This study aimed to assess the sex-dependent prognostic role of body mass index (BMI) in patients with nonmetastatic RCC who underwent radical or partial nephrectomy.

Patients and methods: We retrospectively analyzed 643 consecutive patients with nonmetastatic RCC who underwent curative nephrectomy in our center between 2004 and 2014. Associations among BMI, sex, overall survival (OS), cancer-specific survival (CSS), and metastasis-free survival (MFS) were analyzed.

Results: Males were more likely to have a higher BMI than females (BMI as a categorical variable: $P<0.001$; $\mathrm{BMI}$ as a continuous variable: $P=0.002$ ). In men, a high $\mathrm{BMI}$ was significantly correlated with better 5 -year OS, CSS, and MFS rates $(P=0.001,0.014$, and 0.001, respectively), and multivariate analysis identified that a high BMI was independently associated with greater OS, CSS, and MFS (OS: hazard ratio $[\mathrm{HR}]=0.207, P=0.011$; CSS: $\mathrm{HR}=0.225, P=0.005$; MFS: $\mathrm{HR}=0.243, P=0.004)$. However, in women, there was no significant difference in 5-year OS, CSS, and MFS rates according to BMI ( $P=0.781,0.812$, and 0.538 , respectively). Moreover, a high BMI was no longer independently associated with OS, CSS, or MFS $(P=0.821,0.832$, and 0.801 , respectively). Among patients with clear cell RCC, BMI was significantly associated with OS, CSS, and MFS only among men (all $P<0.05$ ) and not among women (all $P>0.05$ ).

Conclusion: Among patients with nonmetastatic RCC, a high BMI was a favorable prognostic factor in males rather than females. Therefore, sex might influence the correlation between obesity and urological outcomes in nonmetastatic RCC.

Keywords: renal cell carcinoma, body mass index, prognosis, sex

\section{Introduction}

Renal cell carcinoma (RCC) is one of most common malignant tumors of the kidney; its global incidence has increased by about $2 \%$ in the last two decades. ${ }^{1-3}$ In 2008, the numbers of new cases and kidney-cancer related deaths worldwide were approximately 27,400 and 117,000 , respectively. ${ }^{4}$ In Asia, the number of cases of kidney cancer per 100,000 person years in Japan, Singapore, Hong Kong, Shanghai (China), and India was 6.5, 4.3, 3.8, 2.9, and 2.0, respectively, showing Japan as having the highest incidence. ${ }^{5}$ Furthermore, the urological outcomes of RCC patients who underwent curative surgery were not favorable, with approximately $30 \%$ of patients experiencing local or distant recurrence. ${ }^{3}$ Therefore, an increasing number of researchers focus on identifying and evaluating prognostic factors to categorize patients with worse prognosis at early time-points. 
Obesity, as characterized by body mass index (BMI), is a well-known risk factor for $\mathrm{RCC},{ }^{6}$ and the relative risks of RCC increase consistently with obesity in a doseresponse manner. ${ }^{7}$ However, the prognostic value of obesity in RCC patients remains a controversy, with some studies even demonstrating contradictory findings. Some researchers reported no significant relationship between obesity and urological outcomes in RCC, ${ }^{8-10}$ while some others argued that obesity is an independent predictor of prognosis. ${ }^{11,12}$ Furthermore, a previous study demonstrated a nonlinear association between obesity and RCC prognosis. ${ }^{13}$ This phenomenon was called the "obesity paradox". ${ }^{14}$ Therefore, we hypothesized that the significance of obesity in RCC prognosis might be influenced by some factor(s).

A recent study found that a higher BMI is significantly associated with increased risk of RCC among men, but not among women, ${ }^{15}$ suggesting that the relationship between obesity and urological outcomes in RCC might be sexspecific. However, to date, only few studies have reported the prognostic role of obesity in RCC patients according to sex, and the results were conflicting. ${ }^{10,16,17}$ Therefore, this present study aimed to evaluate the sex-dependent role of BMI in predicting the survival outcomes of patients with nonmetastatic RCC who underwent radical or partial nephrectomy.

\section{Patients and methods \\ Patients}

After obtaining institutional review board approval, we retrospectively reviewed 803 consecutive patients with nonmetastatic RCC (pathological T1-4N0M0) following radical or partial nephrectomy between January 2004 and July 2014 at the First Affiliated Hospital of Wenzhou Medical University. The following were excluded from the study: patients with kidney transplantation before surgery, with only one kidney, or with hemodialysis therapy $(n=29)$; patients with a history of any cancer, bilateral RCC, or prior surgery for RCC $(\mathrm{n}=51)$; and patients with $\mathrm{BMI}<18.5 \mathrm{~kg} / \mathrm{m}^{2} \quad(\mathrm{n}=29)$. Patients with incomplete preoperative medical information were also excluded ( $\mathrm{n}=51$ ) (Figure 1). In addition, neoadjuvant chemotherapy was not performed in any patients preoperatively. Finally, 643 patients were included for analysis.

\section{Variables}

The clinicopathological characteristics of patients according to sex are shown in Table 1. These variables were

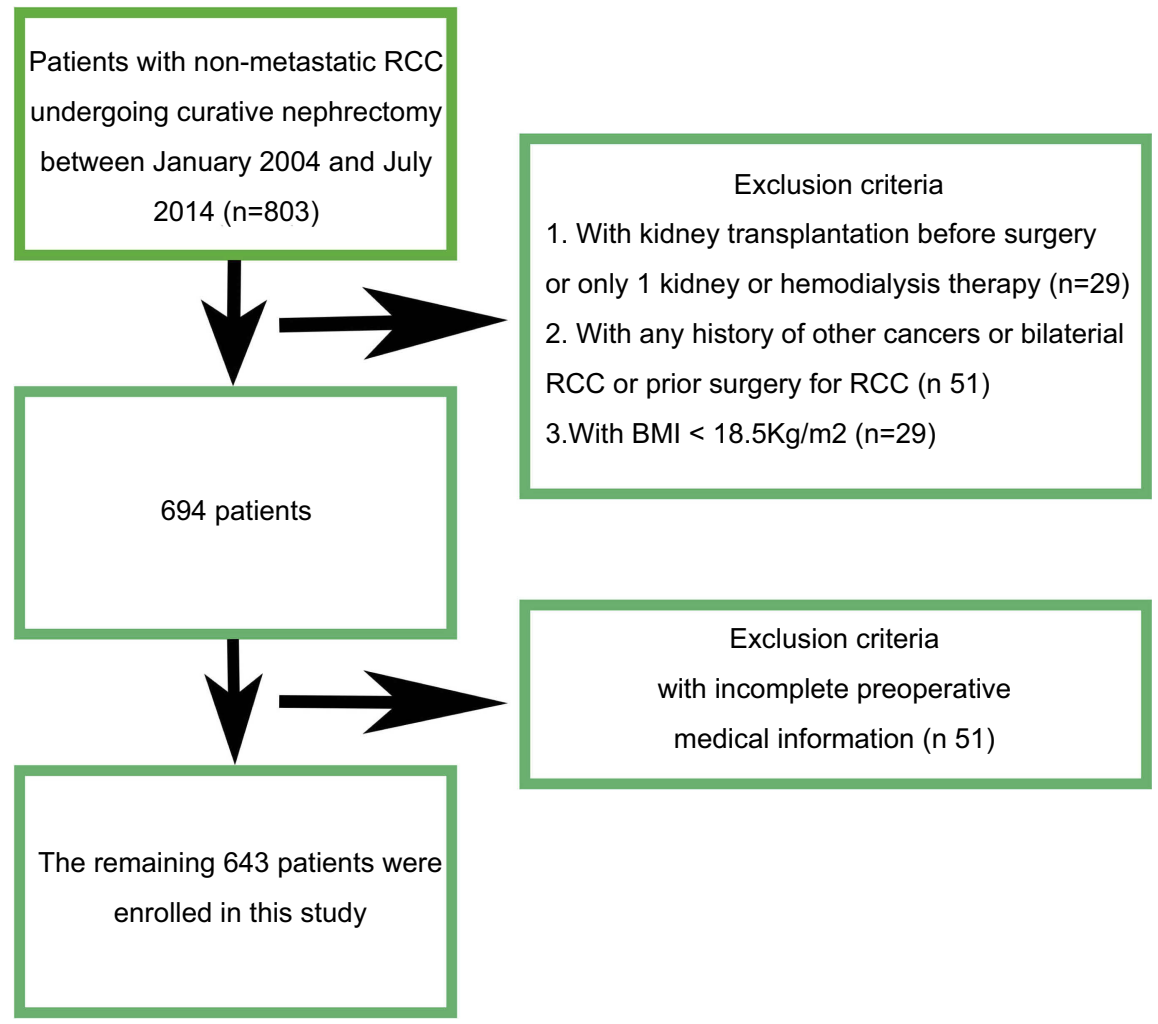

Figure I The patient selection flowchart.

Abbreviations: BMI, body mass index; RCC, renal cell carcinoma. 
Table I Patient characteristics

\begin{tabular}{|c|c|c|c|c|}
\hline Variables & All $(n=643)$ & Male $(n=4 \mid 4)$ & Female $(n=229)$ & $P$-value \\
\hline Age (>65 vs $\leq 65$ years) & $270 / 373$ & $178 / 236$ & $92 / 137$ & 0.488 \\
\hline ASA grade ( $\geq 3$ vs $<3$ ) & $44 / 599$ & $28 / 386$ & $16 / 213$ & 0.914 \\
\hline \multicolumn{5}{|l|}{$\mathrm{BMI}, \mathrm{Kg} / \mathrm{m}^{2}$} \\
\hline (I) Mean $\pm \mathrm{SD}, \mathrm{Kg} / \mathrm{m}^{2}$ & $23.4(2.8)$ & $23.8(2.7)$ & $22.8(2.9)$ & $<0.001 *$ \\
\hline (2) High vs normal BMI & $160 / 483$ & $119 / 295$ & $4 \mid / / 88$ & $0.002 *$ \\
\hline DM (Yes vs No) & $218 / 425$ & I44/270 & $74 / 155$ & 0.527 \\
\hline Hypertension (Yes vs No) & $271 / 372$ & $185 / 229$ & $86 / 143$ & 0.079 \\
\hline Anemia (Yes vs No) & $93 / 550$ & $51 / 363$ & $42 / 187$ & $0.038^{*}$ \\
\hline Surgical approach & & & & 0.193 \\
\hline Partial nephrectomy & 139 & 96 & 43 & \\
\hline Radical nephrectomy & 504 & 318 & 186 & \\
\hline CKD stage & & & & 0.147 \\
\hline CKD I & 424 & 265 & 159 & \\
\hline CKD 2 & 174 & 124 & 50 & \\
\hline CKD 3 & 31 & 17 & 14 & \\
\hline CKD 4 & 5 & 2 & 3 & \\
\hline CKD 5 & 9 & 6 & 3 & \\
\hline Pathologic stage & & & & 0.075 \\
\hline PTI & 499 & 324 & 175 & \\
\hline $\mathrm{pT} 2$ & 75 & 40 & 35 & \\
\hline pT3 & 61 & 43 & 18 & \\
\hline pT4 & 8 & 7 & 1 & \\
\hline Fuhrman grade & & & & 0.851 \\
\hline I & 201 & 130 & 71 & \\
\hline 2 & 277 & 174 & 103 & \\
\hline 3 & 146 & 98 & 48 & \\
\hline 4 & 19 & 12 & 7 & \\
\hline Histologic subtype & & & & $<0.00 I^{*}$ \\
\hline Clear cell & 562 & 367 & 195 & \\
\hline Papillary & 40 & 30 & 10 & \\
\hline Chromophobe & 37 & 13 & 24 & \\
\hline Collecting duct & 1 & 1 & 0 & \\
\hline Unclassified & 3 & 3 & 0 & \\
\hline Clear cell vs non-clear cell & $562 / 81$ & $47 / 367$ & $34 / 195$ & 0.201 \\
\hline Tumor necrosis (Yes vs No) & $22 / 621$ & $15 / 399$ & $7 / 222$ & 0.705 \\
\hline Tumor size ( $\geq 7$ vs $<7 \mathrm{~cm}$ ) & || $2 / 53 \mid$ & $67 / 347$ & $45 / 184$ & 0.267 \\
\hline Follow-up duration, months, median (IQR) & $51.2(30.5-86.4)$ & $48.2(30.1-82.9)$ & $56.3(31.2-92.7)$ & 0.088 \\
\hline All -cause death, $n(\%)$ & $57(8.9)$ & $43(10.4)$ & $14(6.1)$ & 0.093 \\
\hline Cancer-specific death, n(\%) & $39(6.1)$ & $25(6.0)$ & $14(6.1)$ & 0.970 \\
\hline Metastasis, n(\%) & $7 I(I I .0)$ & $54(13.0)$ & $17(7.4)$ & $0.029 *$ \\
\hline
\end{tabular}

Note: *Statistically significant.

Abbreviations: ASA, American Society of Anesthesiologists; IQR, interquartile range; DM, diabetes mellitus; CKD, chronic kidney disease. 
Table 2 Multivariate analysis of variables for the prediction of OS in all patients

\begin{tabular}{|c|c|c|c|c|c|c|}
\hline \multirow[t]{2}{*}{ Variables } & \multicolumn{3}{|c|}{ BMI as categorical variable } & \multicolumn{3}{|c|}{ BMI as continuous variable } \\
\hline & HR & $95 \% \mathrm{Cl}$ & $P$-value & HR & $95 \% \mathrm{Cl}$ & $P$-value \\
\hline Age (>65 vs $\leq 65$ years) & 3.359 & $1.716-6.575$ & $<0.00 I^{*}$ & 4.781 & $2.303-9.931$ & $<0.00 I^{*}$ \\
\hline Gender (men vs women) & 1.935 & $1.026-3.649$ & $0.042 *$ & 2.066 & $1.023-4.173$ & 0.043* \\
\hline ASA grade ( $\geq 3$ vs $<3$ ) & 1.577 & $0.778-3.199$ & 0.207 & 1.955 & $0.813-4.702$ & 0.134 \\
\hline $\begin{array}{l}\text { BMI, } \mathrm{Kg} / \mathrm{m}^{2} \\
\text { (I) Category: } \geq 25 \text { vs }<25 \\
\text { (2) Continuous }\end{array}$ & 0.326 & $\begin{array}{l}0.126-0.842 \\
-\end{array}$ & $0.021 *$ & 0.857 & $\begin{array}{l}- \\
0.747-982\end{array}$ & $0.027^{*}$ \\
\hline Anemia (Yes vs No) & 1.806 & $1.004-3.246$ & $0.048 *$ & 2.341 & $1.146-4.784$ & $0.020^{*}$ \\
\hline Surgical approach (partial vs radical) & 0.831 & $0.318-2.175$ & 0.706 & 0.600 & $0.214-1.678$ & 0.330 \\
\hline $\begin{array}{l}\text { CKD stage } \\
\text { CKD I } \\
\text { CKD } 2-3 \text { vs CKD । } \\
\text { CKD 4-5 vs CKD I }\end{array}$ & $\begin{array}{l}1.000 \\
1.572 \\
5.544\end{array}$ & $\begin{array}{l}\text { Reference } \\
0.889-2.782 \\
1.746-17.605\end{array}$ & $\begin{array}{l}1.000 \\
0.120 \\
\mathbf{0 . 0 0 4}\end{array}$ & $\begin{array}{l}1.000 \\
1.639 \\
1.695\end{array}$ & $\begin{array}{l}\text { Reference } \\
0.854-3.147 \\
0.386-7.446\end{array}$ & $\begin{array}{l}1.000 \\
0.138 \\
0.485\end{array}$ \\
\hline $\begin{array}{l}\text { Pathologic stage } \\
\text { PTI } \\
\text { PT2 vs PTI } \\
\text { PT3 vs PTI } \\
\text { PT4 vs PTI }\end{array}$ & $\begin{array}{l}1.000 \\
1.793 \\
2.211 \\
3.789\end{array}$ & $\begin{array}{l}\text { Reference } \\
0.710-4.531 \\
0.997-4.900 \\
0.686-20.926\end{array}$ & $\begin{array}{l}1.000 \\
0.217 \\
0.051 \\
0.006 *\end{array}$ & $\begin{array}{l}1.000 \\
2.200 \\
1.988 \\
2.847\end{array}$ & $\begin{array}{l}\text { Reference } \\
0.723-6.691 \\
0.780-5.067 \\
0.333-24.305\end{array}$ & $\begin{array}{l}1.000 \\
0.165 \\
0.150 \\
0.009 *\end{array}$ \\
\hline Fuhrman grade ( $\geq 3$ vs $<3$ ) & 1.953 & $1 .|12-3.43|$ & $0.020 *$ & 2.312 & $1.232-4.336$ & $0.009 *$ \\
\hline Tumor necrosis (yes vs no) & 1.916 & $0.670-5.486$ & 0.225 & 1.728 & $0.467-6.398$ & 0.413 \\
\hline Tumor size ( $\geq 7$ vs $<7$ ) & 1.593 & $0.703-3.608$ & 0.265 & 1.457 & $0.552-3.849$ & 0.448 \\
\hline
\end{tabular}

Note: *Statistically significant.

Abbreviations: BMI, body mass index; CKD, chronic kidney disease; OS, overall survival.

retrospectively obtained from a prospectively maintained computer database at our center. BMI was measured before surgery and categorized as normal BMI $\left(<25 \mathrm{~kg} / \mathrm{m}^{2}\right)$ and high BMI $\left(\geq 25 \mathrm{~kg} / \mathrm{m}^{2}\right.$; obesity $) .{ }^{18-20}$ The $\mathrm{T}$ stage and histological subtype of tumors were determined based on the seventh edition of the TNM classification by the Union for International Cancer Control, the guidelines by the American Joint Committee on Cancer, and the Heidelberg recommendations. Nuclear grade was evaluated using the Fuhrman grading system. Tumor size was defined as the largest diameter of the tumor according to the pathological report. The pathological features of tumors were evaluated by urological pathologists. Postoperative follow-up care consisted of blood and urine tests, and chest and abdominal computed tomography or magnetic resonance imaging every 3 to 6 months for the first 2 years and annually thereafter. The follow-up cutoff was September 1, 2016. Overall survival (OS), cancer-specific survival (CSS), and metastasis-free survival (MFS) were calculated from the date of surgery to the (a) date of death from any cause, (b) date of causespecific death, and (c) date of the last follow-up of recurrence of radiologically or histologically confirmed distant metastasis, respectively.

\section{Statistical analysis}

All statistical analyses were performed using SPSS software package version 25.0 (IBM, Armonk, NY). All $P$-values were two-tailed, and $P<0.05$ was considered statistically significant. Relationships between patients' clinicopathological characteristics and sex were compared using Student's test for continuous variables and Pearson's chi-square test for categorical variables. Trends of variables for different BMIs were analyzed using the Cochran-Armitage test. OS, CSS, and MFS rates were estimated using the Kaplan-Meier method stratified according to BMI for all patients, men, and women. The prognostic values of BMIs as categorical and continuous variables were evaluated using univariate 
analysis and multivariate Cox regression analysis. Other variables were also analyzed, including age, American Society of Anesthesiologists (ASA) grade, diabetes mellitus (DM), hypertension, anemia, surgical approach, chronic kidney disease (CKD) stage, pathological stage, Fuhrman grade, histological subtype, tumor necrosis, and tumor size. Additionally, variables with $P<0.1$ in the univariate analysis were included in the multivariate model.

\section{Results}

\section{Associations between BMI, sex, and clinical and pathological characteristics}

Table 1 shows the associations of clinical and pathological factors with sex. Overall, there were 414 (64.4\%) males and $229(35.6 \%)$ females, with a male-to female ratio of 1.81:1. The mean age of this cohort was 61.59 (standard deviation, 12.67) years, and the median follow-up duration was 51.2 (interquartile range, 30.5-86.4) months. There were no significant differences between men and women according to age and follow-up duration $(P=0.488$ and $P=0.088$, respectively). Men were more likely to have significantly higher BMI than women $(P<0.05)$. Furthermore, the BMI in men significantly decreased with ageing $(\mathrm{r}=-0.028, P=0.006)$ (Figure 2A); however, BMI in women tended to increase with age ( $\mathrm{r}=0.007, P=0.656)$ (Figure $2 \mathrm{~B})$. In addition, men were more likely to be anemia and had higher risk of metastasis ( $P=0.038$ and $P=0.029$, respectively).

\section{Overall survival according to $\mathrm{BMI}$ and sex}

During the follow-up, 57 (8.9\%) patients died (Table 1). In all population, the 5-year OS rates were $88.7 \%$ and $97.8 \%$ in patients with normal BMI and high BMI, respectively $(P=0.004) \quad$ (Figure 3A). BMI was identified as an independent favorable factor of OS (BMI as a categorical variable: $\mathrm{HR}=0.326, P=0.021 ; \mathrm{BMI}$ as a continuous variable: $\mathrm{HR}=0.857, P=0.027$ ) through univariate analysis and multivariate analysis (Tables S1-S3, Table 2, and Figure 4A and B). In men, the 5-year OS rates were $85.5 \%$ and $98.1 \%$ in patients with normal BMI and high BMI, respectively $(P=0.001)$ (Figure 3B). BMI was also identified as an independent favorable factor of OS in men (BMI as a categorical variable: $\mathrm{HR}=0.207, P=0.011 ; \mathrm{BMI}$ as a continuous variable: $\mathrm{HR}=0.805, P=0.012$ ) according to univariate analysis and multivariate analysis (Table 3, and Figure 4). However, in women, there was no significant difference between normal BMI patients and high BMI patients with $93.3 \%$ and $91.8 \%$ 5-year OS rates, respectively $(P=0.781)$ (Figure $3 \mathrm{C}$ ). Furthermore, BMI was not an independent predictor of OS in women (BMI as a categorical variable: $H R=1.201$, $P=0.821$; $\mathrm{BMI}$ as a continuous variable: $\mathrm{HR}=0.990$, $P=0.934$ ) (Table 3, and Figure 4).

\section{CSS according to BMI and sex}

During the follow-up, 39 (6.1\%) patients died due to RCC (Table 1). In all population, the 5-year CSS rates were $91.6 \%$ and $97.3 \%$ in patients with normal BMI and high BMI, respectively $(P=0.029)$ (Figure $5 \mathrm{~A})$. BMI was identified as an independent favorable factor of CSS (BMI as a categorical variable: $\mathrm{HR}=0.425, P=0.019$; $\mathrm{BMI}$ as a continuous variable: $\mathrm{HR}=0.891, P=0.047)$ using univariate analysis and multivariate analysis (Table S2, Tables 4 and 5, and Figure 6). In men, the 5-year CSS rates were $90.4 \%$ and $99.1 \%$ in patients with normal BMI and high BMI, respectively $(P=0.014)$ (Figure 5B). BMI was also identified as an independent favorable factor of CSS in men (BMI as a categorical variable: $\mathrm{HR}=0.225, P=0.005$; $\mathrm{BMI}$ as a continuous variable:
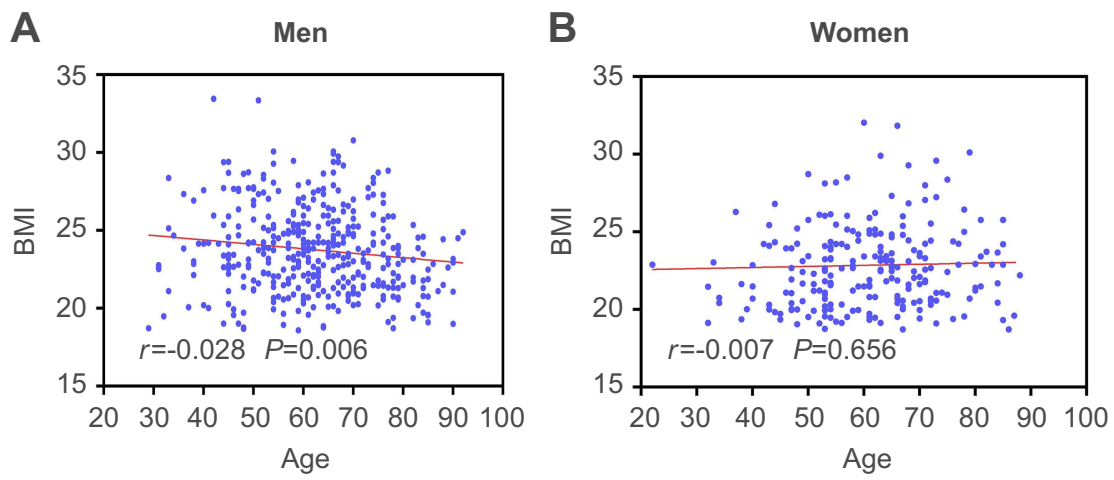

Figure 2 Correlation between age and BMI. The BMI in men significantly decreased when they were ageing $(\mathbf{A})$; however, the BMI in women increased with increasing age while the relationship was not significant (B).

Abbreviation: BMI, Body mass index. 

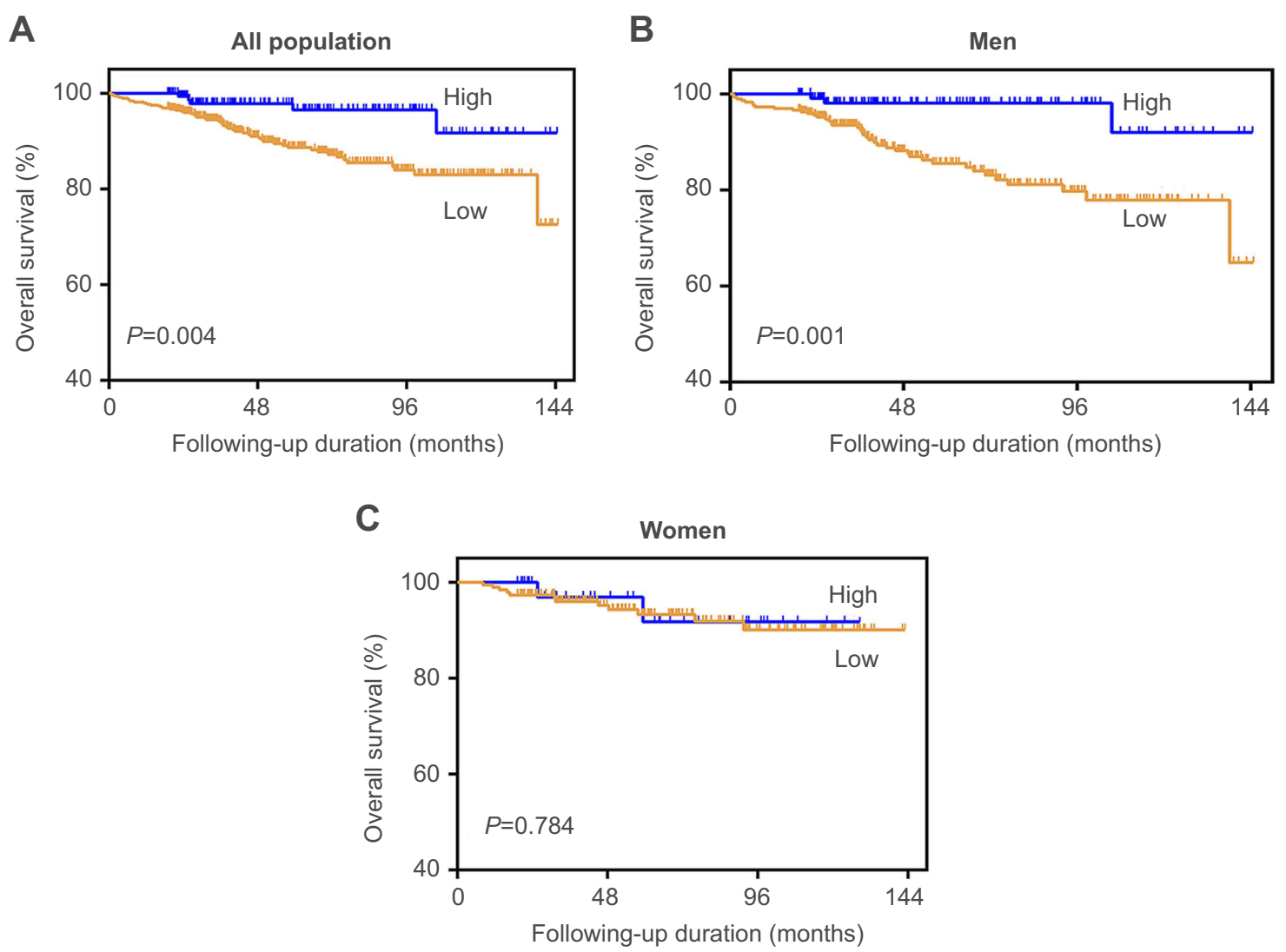

Figure 3 Kaplan-Meier curves for overall survival stratified by BMI in all patients (A), male patients (B), and female patients (C) with non-metastasis RCC. Abbreviations: BMI, body mass index; RCC, renal cell carcinoma.

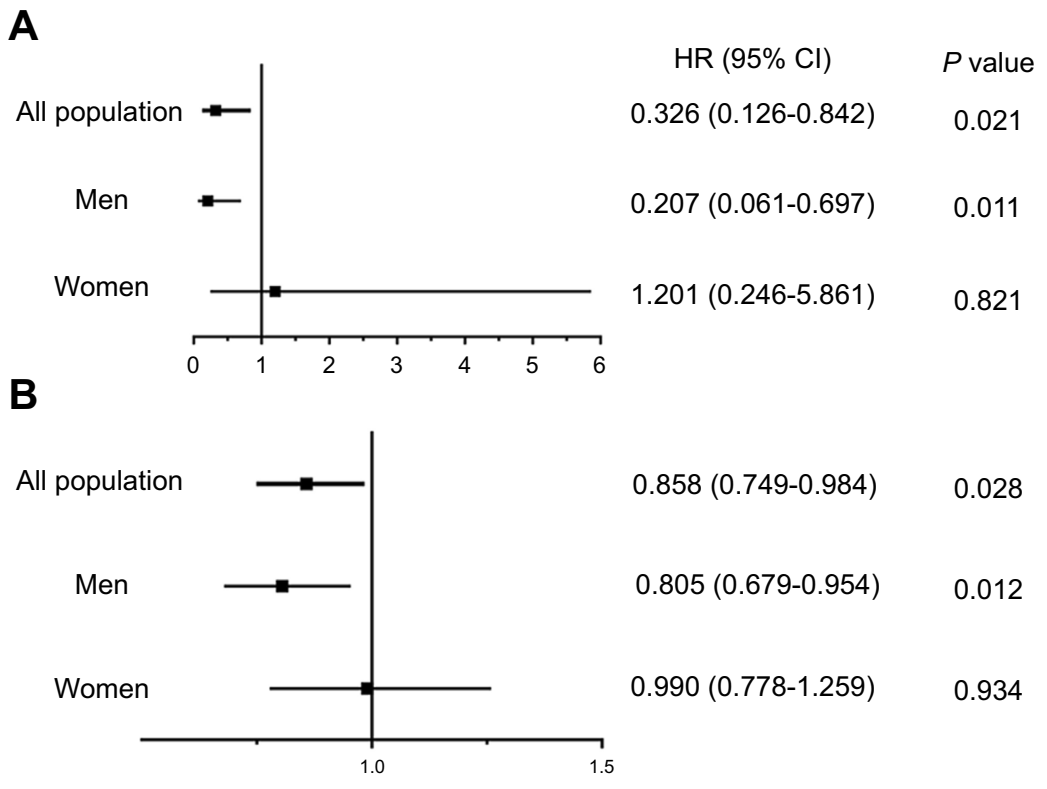

Figure $4 \mathrm{HRs}$ and $95 \% \mathrm{Cls}$ for overall survival by $\mathrm{BMI}$ as categorical variable (A) or continuous variable (B).

Abbreviation: BMI, body mass index.

$\mathrm{HR}=0.817, P=0.027)$ according to univariate analysis and multivariate analysis (Table 5, and Figure 6). Nevertheless, in women, the 5-year CSS rates were $93.3 \%$ and $91.8 \%$ in patients with normal BMI and high BMI, respectively. There was no significant difference between the two groups ( $P=0.812$ ) (Figure $5 \mathrm{C}$ ), and BMI was not an independent 
Table 3 The significance of BMI for the prediction of OS using multivariate analysis by sex

\begin{tabular}{|c|c|c|c|c|c|c|c|}
\hline \multirow[t]{2}{*}{ Sex } & \multicolumn{4}{|c|}{ BMI as categorical variable } & \multicolumn{3}{|c|}{ BMI as continuous variable } \\
\hline & & HR & $95 \% \mathrm{Cl}$ & $P$-value & HR & $95 \% \mathrm{Cl}$ & $P$-value \\
\hline All & High vs normal BMI & 0.326 & $0.126-0.842$ & $0.02 I^{*}$ & 0.858 & $0.749-0.984$ & $0.028 *$ \\
\hline Men & High vs normal BMI & 0.207 & $0.06 \mathrm{I}-0.697$ & $0.011^{*}$ & 0.805 & $0.679-0.954$ & $0.012 *$ \\
\hline Women & High vs normal BMI & 1.201 & $0.246-5.861$ & 0.821 & 0.990 & $0.778-1.259$ & 0.934 \\
\hline
\end{tabular}

Note: *Statistically significant.

Abbreviations: BMI, body mass index; OS, overall survival.
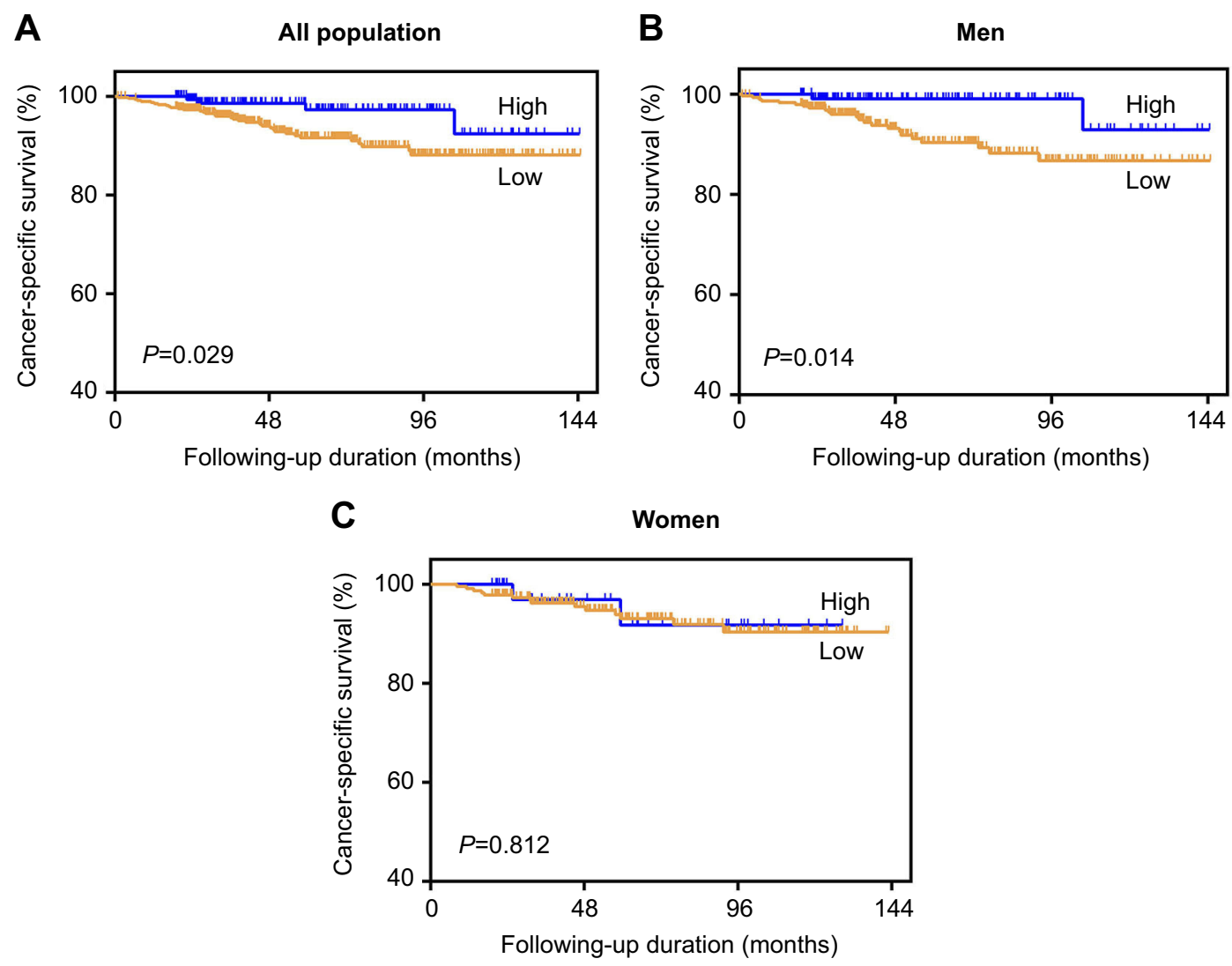

Figure 5 Kaplan-Meier curves for cancer-specific survival stratified by BMI in all patients (A), male patients (B), and female patients (C) with non-metastasis RCC. Abbreviations: BMI, body mass index; RCC, renal cell carcinoma.

factor of CSS in women (BMI as a categorical variable: $\mathrm{HR}=1.193, \quad P=0.832$; $\mathrm{BMI}$ as a continuous variable: $\mathrm{HR}=0.990, P=0.934$ ) (Table 5 and Figure 6A and $\mathrm{B}$ ).

\section{MFS according to BMI and sex}

During the follow-up, $71(11.0 \%)$ patients experienced metastasis (Table 1). In all population, the 5-year MFS rates were $85.7 \%$ and $96.6 \%$ in patients with normal BMI and high BMI, respectively ( $P=0.002$ ) (Figure 7A). BMI was identified as an independent favorable factor of MFS (BMI as a categorical variable: $\mathrm{HR}=0.331, P=0.007$; $\mathrm{BMI}$ as a continuous variable: $\mathrm{HR}=0.895, \quad P=0.047$ ) using univariate analysis and multivariate analysis (Table S3, Tables 6 and 7, and Figure 8). In men, the 5-year MFS rates were $90.4 \%$ and $99.1 \%$ in patients with normal BMI and high BMI, respectively $(P=0.001)$ (Figure 7B). BMI was also identified as an independent favorable factor of MFS in men (BMI as a categorical variable: $\mathrm{HR}=0.243, P=0.004$; $\mathrm{BMI}$ as a continuous variable: $\mathrm{HR}=0.865, P=0.044$ ) according to univariate analysis and multivariate analysis (Table 7, and Figure 8). Nevertheless, in women, the 5-year MFS rates were $93.3 \%$ and $91.8 \%$ in patients with normal BMI and high BMI, respectively. There was no significant difference between the two groups $(P=0.538)$ (Figure $7 \mathrm{C})$, and BMI was not an independent 
Table 4 Multivariate analysis of variables for the prediction of CSS in all patients

\begin{tabular}{|c|c|c|c|c|c|c|}
\hline \multirow[t]{2}{*}{ Variables } & \multicolumn{3}{|c|}{ BMI as categorical variable } & \multicolumn{3}{|c|}{ BMI as continuous variable } \\
\hline & HR & $95 \% \mathrm{Cl}$ & $P$-value & HR & $95 \% \mathrm{Cl}$ & $P$-value \\
\hline Age ( $>65$ vs $\leq 65$ years) & 3.191 & $1.460-6.977$ & $0.004 *$ & 4.121 & $1.767-9.610$ & $0.001 *$ \\
\hline ASA grade ( $\geq 3$ vs $<3$ ) & 1.649 & $0.698-3.896$ & 0.255 & 2.031 & $0.735-5.611$ & 0.172 \\
\hline $\begin{array}{l}\text { BMI, } \mathrm{Kg} / \mathrm{m}^{2} \\
\text { (I) Category: } \geq 25 \text { vs }<25 \\
\text { (2) Continuous }\end{array}$ & 0.425 & $\begin{array}{l}0.145-1.245 \\
-\end{array}$ & $0.019 *$ & 0.891 & $\begin{array}{l}- \\
0.762-1.043\end{array}$ & $0.047^{*}$ \\
\hline Anemia (yes vs no) & 1.505 & $0.742-3.052$ & 0.257 & 1.795 & $0.784-4.113$ & 0.166 \\
\hline Surgical approach (partial vs radical) & & - & & 0.599 & $0.166-2.168$ & 0.435 \\
\hline $\begin{array}{l}\text { CKD stage } \\
\text { CKD I } \\
\text { CKD 2-3 vs CKD I } \\
\text { CKD 4-5 vs CKD I }\end{array}$ & $\begin{array}{l}1.000 \\
1.998 \\
2.033\end{array}$ & $\begin{array}{l}\text { Reference } \\
1.013-3.943 \\
0.255-16.192\end{array}$ & $\begin{array}{l}1.000 \\
0.046 * \\
0.503\end{array}$ & $\begin{array}{l}1.000 \\
2.152 \\
0.518\end{array}$ & $\begin{array}{l}\text { Reference } \\
0.998-4.639 \\
0.053-5.064\end{array}$ & $\begin{array}{l}1.000 \\
0.051 \\
0.571\end{array}$ \\
\hline $\begin{array}{l}\text { Pathologic stage } \\
\text { PTI } \\
\text { PT2 vs PTI } \\
\text { PT3 vs PTI } \\
\text { PT4 vs PTI }\end{array}$ & $\begin{array}{l}1.000 \\
1.610 \\
2.752 \\
6.593\end{array}$ & $\begin{array}{l}\text { Reference } \\
0.542-4.778 \\
1.078-7.028 \\
1.102-39.426\end{array}$ & $\begin{array}{l}1.000 \\
0.391 \\
0.034^{*} \\
0.039^{*}\end{array}$ & $\begin{array}{l}1.000 \\
1.693 \\
2.380 \\
4.507\end{array}$ & $\begin{array}{l}\text { Reference } \\
0.497-5.764 \\
0.834-6.788 \\
0.521-38.995\end{array}$ & $\begin{array}{l}1.000 \\
0.399 \\
0.105 \\
\mathbf{0 . 1 7 1}\end{array}$ \\
\hline Fuhrman grade ( $\geq 3$ vs $<3$ ) & 2.854 & $1.439-5.662$ & 0.003* & 3.073 & $1.465-6.446$ & $0.003 *$ \\
\hline Tumor necrosis (yes vs no) & 2.661 & $0.906-7.818$ & 0.075 & 2.625 & $0.681-10.123$ & 0.161 \\
\hline Tumor size ( $\geq 7$ vs $<7$ ) & 2.403 & $0.943-6.123$ & 0.066 & 2.537 & $0.888-7.247$ & 0.082 \\
\hline
\end{tabular}

Note: *Statistically significant.

Abbreviations: BMI, body mass index; CSS, cancer-specific survival; CKD, chronic kidney disease.

Table 5 The significance of BMI for the prediction of CSS using multivariate analysis by sex

\begin{tabular}{|c|c|c|c|c|c|c|c|}
\hline \multirow[t]{2}{*}{ Sex } & \multicolumn{4}{|c|}{ BMI as categorical variable } & \multicolumn{3}{|c|}{ BMI as continuous variable } \\
\hline & & HR & $95 \% \mathrm{Cl}$ & $P$-value & HR & $95 \% \mathrm{Cl}$ & $P$-value \\
\hline All & High vs normal BMI & 0.425 & $0.145-1.245$ & $0.019^{*}$ & 0.891 & $0.762-1.043$ & $0.047^{*}$ \\
\hline Men & High vs normal BMI & 0.225 & $0.049-1.034$ & $0.005^{*}$ & 0.817 & $0.658-1.014$ & $0.027^{*}$ \\
\hline Women & High vs normal BMI & 1.193 & $0.234-6.07 \mid$ & 0.832 & 0.990 & $0.778-1.259$ & 0.934 \\
\hline
\end{tabular}

Note: *Statistically significant.

Abbreviations: BMI, body mass index; CSS, cancer-specific survival.

factor of MFS in women (BMI as a categorical variable: $\mathrm{HR}=0.820, \quad P=0.801 ; \quad \mathrm{BMI}$ as a continuous variable: $\mathrm{HR}=0.926, P=0.504)($ Table 7 and Figure $8 \mathrm{~A}$ and $\mathrm{B})$.

\section{Associations between BMI, sex, and urological outcomes in patients with clear cell RCC}

As shown in Table 8, there were 367 (65.3\%) males and 195 (34.7\%) females, with a male-to-female ratio of $1.88: 1$. Men were more likely to have significantly higher BMI than women $(P<0.05)$. There were no significant differences between men and women in terms of other factors. As shown in Table 9, the BMI of patients with clear cell RCC was significantly associated with OS (BMI as a categorical variable: $\mathrm{HR}=0.158, P=0.013$; $\mathrm{BMI}$ as a continuous variable: $\mathrm{HR}=0.798, P=0.017$ ), $\mathrm{CSS}$ (BMI as a categorical variable: $\mathrm{HR}=0.104, P=0.036$; $\mathrm{BMI}$ as a continuous variable: HR=0.756, $P=0.032$ ), and MFS (BMI as a categorical variable: $\mathrm{HR}=0.229, P=0.007$; $\mathrm{BMI}$ as a continuous variable: $\mathrm{HR}=0.869, \quad P=0.003$ ) only among men, and not among women (all $P>0.05$ ). 


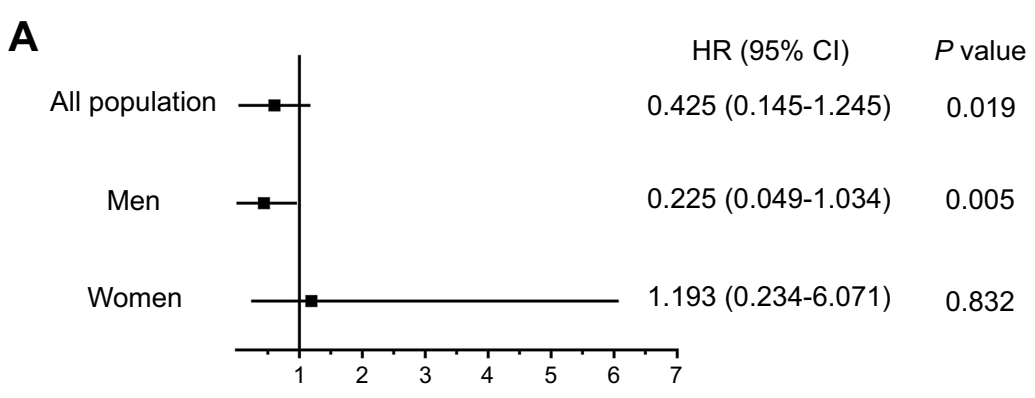

B

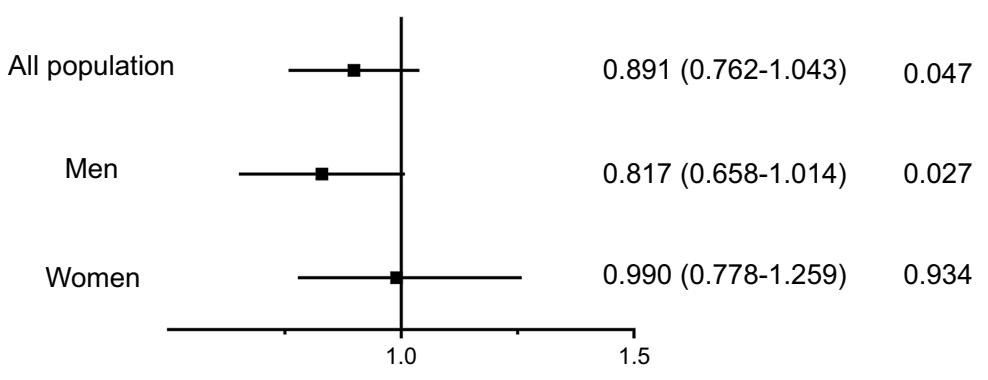

Figure 6 HRs and95\% Cls for cancer-specific survival by BMI as categorical variable (A) or continuous variable (B). Abbreviation: BMI, body mass index.
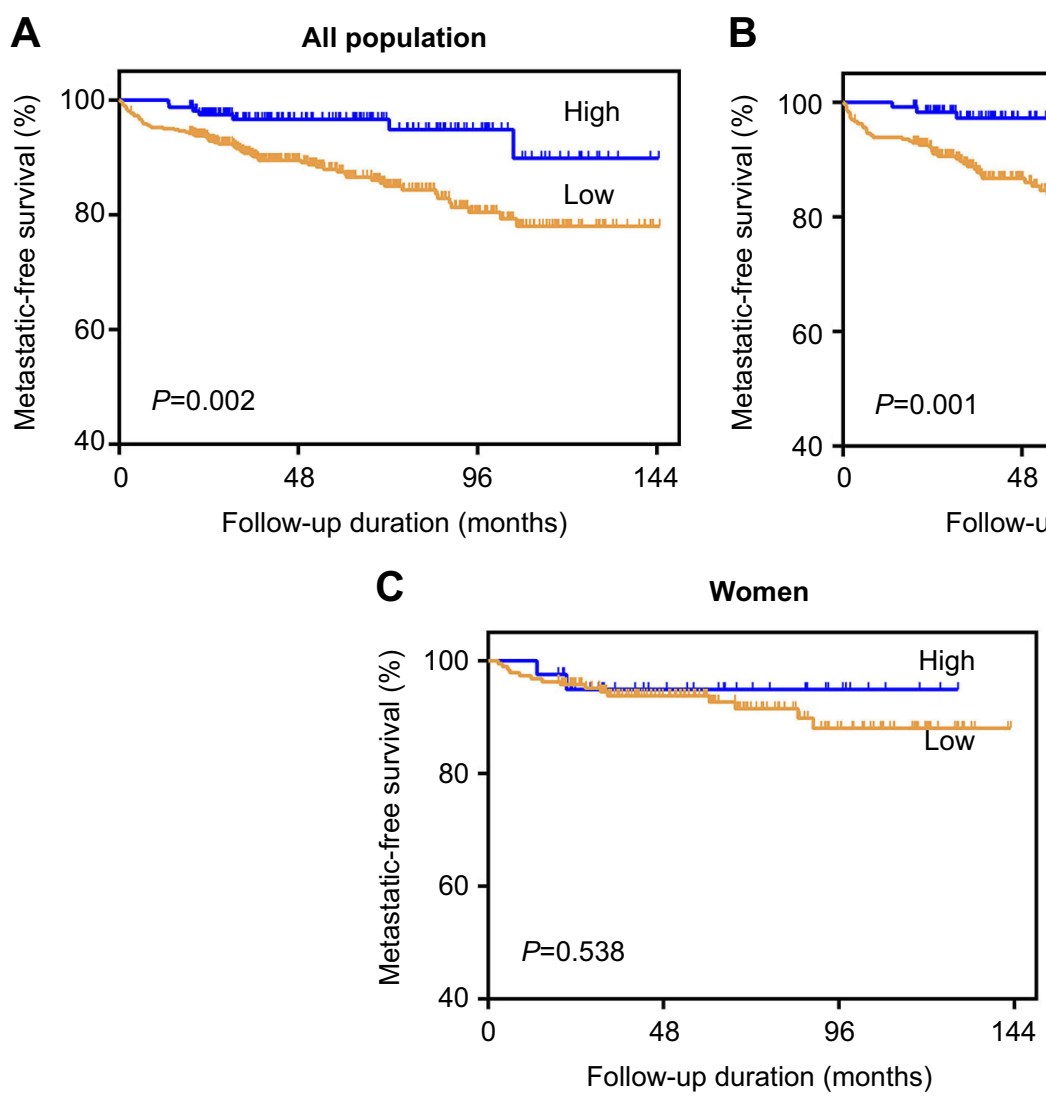

Women

Figure 7 Kaplan-Meier curves for metastasis-free survival stratified by BMI in all patients (A), male patients (B), and female patients (C) with non-metastasis RCC. Abbreviations: BMI, body mass index; RCC, renal cell carcinoma.

\section{Discussion}

The results of this study revealed that BMI was an independent predictor of OS, CSS, and MFS in patients with

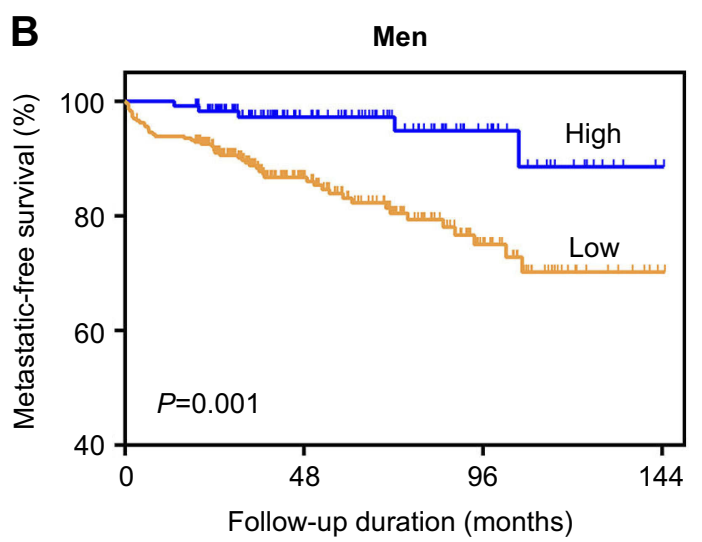


Table 6 Multivariate analysis of variables for the prediction of MFS in all patients

\begin{tabular}{|c|c|c|c|c|c|c|}
\hline \multirow[t]{2}{*}{ Variables } & \multicolumn{3}{|c|}{ BMI as categorical variable } & \multicolumn{3}{|c|}{ BMI as continuous variable } \\
\hline & HR & $95 \% \mathrm{Cl}$ & $P$-value & HR & $95 \% \mathrm{Cl}$ & $P$-value \\
\hline Age (>65 vs $\leq 65$ years) & 3.191 & $1.460-6.977$ & $0.004 *$ & 2.832 & $1.570-5.110$ & 0.001 \\
\hline Gender (men vs women) & 2.375 & $1.336-4.223$ & $0.003 *$ & 2.171 & $1.164-4.048$ & 0.015 \\
\hline ASA grade $(\geq 3$ vs $<3$ ) & 1.125 & $0.525-2.413$ & 0.761 & 1.095 & $0.452-2.653$ & 0.841 \\
\hline $\begin{array}{l}\text { BMI, } \mathrm{Kg} / \mathrm{m}^{2} \\
\text { (I) Category: } \geq 25 \text { vs }<25 \\
\text { (2) Continuous }\end{array}$ & 0.331 & $\begin{array}{l}0.147-0.744 \\
-\end{array}$ & $0.007^{*}$ & 0.895 & $\begin{array}{l}- \\
0.799-1.003\end{array}$ & $0.047 *$ \\
\hline Hypertension (yes vs no) & 1.090 & $0.647-1.835$ & 0.746 & & - & \\
\hline Anemia (yes vs no) & 1.505 & $0.742-3.052$ & 0.257 & 1.797 & $0.924-3.492$ & 0.084 \\
\hline Surgical approach (partial vs radical) & 0.796 & $0.352-1.797$ & 0.582 & 0.586 & $0.248-1.385$ & 0.586 \\
\hline $\begin{array}{l}\text { CKD stage } \\
\text { CKD I } \\
\text { CKD } 2-3 \text { vs CKD । } \\
\text { CKD 4-5 vs CKD I }\end{array}$ & $\begin{array}{l}1.000 \\
1.429 \\
6.103\end{array}$ & $\begin{array}{l}\text { Reference } \\
0.858-2.379 \\
2.097-17.764\end{array}$ & $\begin{array}{l}1.000 \\
0.170 \\
0.00 I^{*}\end{array}$ & $\begin{array}{l}1.000 \\
1.654 \\
2.858\end{array}$ & $\begin{array}{l}\text { Reference } \\
0.931-2.937 \\
0.737-11.081\end{array}$ & $\begin{array}{l}1.000 \\
0.086 \\
0.129\end{array}$ \\
\hline $\begin{array}{l}\text { Pathologic stage } \\
\qquad \text { PTI } \\
\text { PT2 vs PTI } \\
\text { PT3 vs PTI } \\
\text { PT4 vs PTI }\end{array}$ & $\begin{array}{l}1.000 \\
1.885 \\
2.112 \\
3.288\end{array}$ & $\begin{array}{l}\text { Reference } \\
0.815-4.360 \\
1.017-4.384 \\
0.657-16.450\end{array}$ & $\begin{array}{l}1.000 \\
0.139 \\
0.045^{*} \\
0.147\end{array}$ & $\begin{array}{l}1.000 \\
1.927 \\
1.583 \\
1.976\end{array}$ & $\begin{array}{l}\text { Reference } \\
0.722-5.143 \\
0.682-3.679 \\
0.290-13.460\end{array}$ & $\begin{array}{l}1.000 \\
0.191 \\
0.285 \\
0.486\end{array}$ \\
\hline Fuhrman grade ( $\geq 3$ vs $<3$ ) & 1.652 & $1.006-2.714$ & $0.047^{*}$ & 2.088 & $1.198-3.639$ & 0.009 \\
\hline Tumor necrosis (yes vs no) & 3.277 & $1.345-7.986$ & $0.009 *$ & & - & \\
\hline Tumor size ( $\geq 7$ vs $<7$ ) & 1.480 & $0.708-3.093$ & 0.298 & 1.550 & $0.655-3.668$ & 0.319 \\
\hline
\end{tabular}

Note: *Statistically significant.

Abbreviations: BMI, body mass index; CKD, chronic kidney disease; MFS, metastasis-free survival.

Table 7 The significance of BMI for the prediction of MFS using multivariate analysis by sex

\begin{tabular}{|c|c|c|c|c|c|c|c|}
\hline \multirow[t]{2}{*}{ Sex } & \multicolumn{4}{|c|}{ BMI as categorical variable } & \multicolumn{3}{|c|}{ BMI as continuous variable } \\
\hline & & HR & $95 \% \mathrm{Cl}$ & $P$-value & HR & $95 \% \mathrm{Cl}$ & $P$-value \\
\hline All & High vs normal BMI & 0.331 & $0.147-0.744$ & $0.007 *$ & 0.895 & $0.799-1.003$ & $0.047^{*}$ \\
\hline Men & High vs normal BMI & 0.243 & $0.093-0.638$ & $0.004^{*}$ & 0.865 & $0.75 I-0.996$ & $0.044^{*}$ \\
\hline Women & High vs normal BMI & 0.820 & $0.175-3.848$ & 0.801 & 0.926 & $0.739-1.160$ & 0.504 \\
\hline
\end{tabular}

Note: *Statistically significant.

Abbreviations: BMI, body mass index; MFS, metastasis-free survival.

a significantly higher BMI than women. Moreover, a high BMI was significantly associated with favorable OS, CSS, and MFS in men, but not in women, with RCC. The same findings were observed among patients with clear cell RCC. To our knowledge, this is the first study to assess the prognostic influence of BMI on nonmetastatic RCC according to sex.
To date, four studies have assessed the associations between sex, BMI, and survival outcomes in RCC..$^{10,16,17,22}$ Donat et al (2006) retrospectively reviewed 1137 consecutive patients with RCC who underwent radical or partial nephrectomy between 1995 and 2003, to evaluate the influence of BMI on survival in RCC patients. ${ }^{10}$ Their results did not show a significant difference in OS or progression-free 


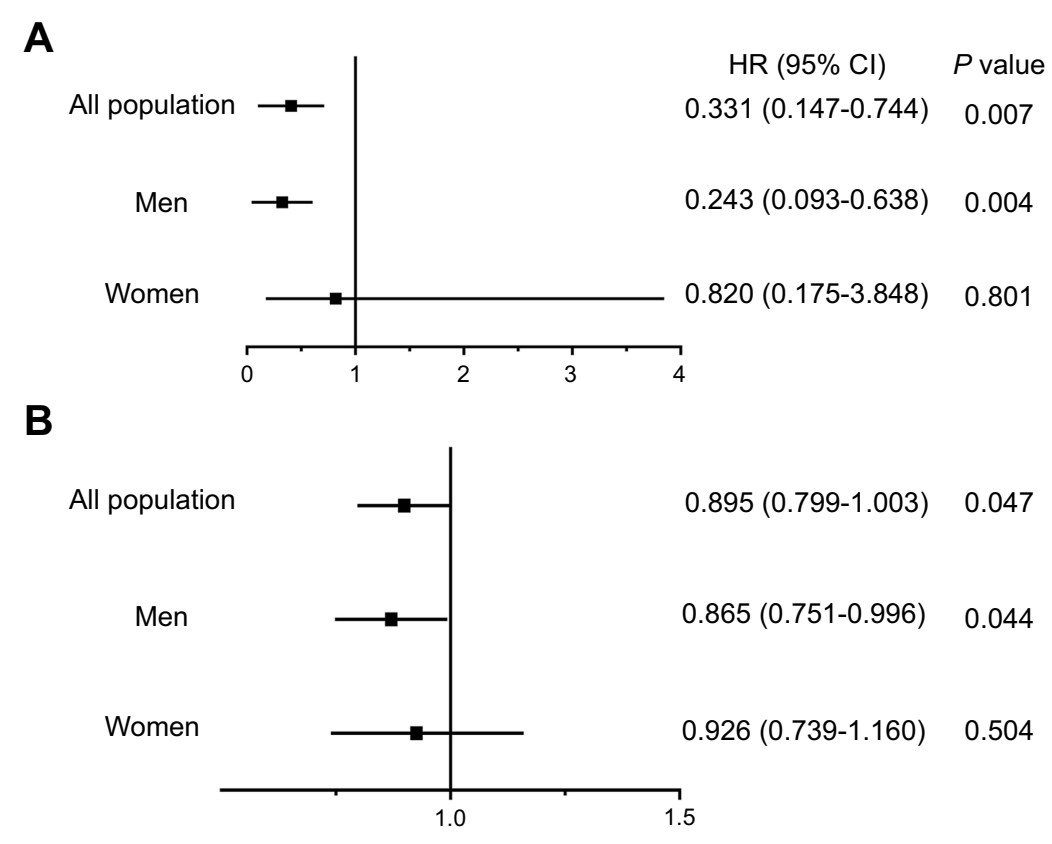

Figure $8 \mathrm{HRs}$ and $95 \% \mathrm{Cls}$ for metastasis-free survival by BMl as categorical variable (A) or continuous variable (B).

Abbreviation: BMI, body mas index.

survival based on BMI between males and females. Moreover, their study included all RCC patients but not exclude those with metastasis. Because the natural history, clinicopathological features, and subsequent treatment of metastatic RCC are commonly different from those of nonmetastatic RCC, ${ }^{3}$ such difference might have influenced the associations between sex, BMI, and RCC prognosis demonstrated in their study. Reeves et al (2007) also recruited 1.2 million women from the UK who were aged 50-64 years during 1996-2001, to examine the relationship between BMI and incidence of and mortality from cancer, including kidney cancer. $^{22}$ They reported that increased BMI is associated with increased incidence of and mortality from kidney cancer among women. Although their study had a large sample size, it did not include well-known prognostic factors of RCC, such as pathological stage and nuclear grade. Therefore, their conclusion about kidney cancer requires evaluation. Years after, Ohno et al (2013) retrospectively analyzed 435 patients with clear cell RCC. ${ }^{17}$ Their results demonstrated that BMI is significantly associated with CSS among all patients and men, but not among women. Although their results were consistent with ours, their research had two limitations: First, the male-to-female ratio of 2.7:1 for RCC was much higher than the recommended ratio of 1.5:1 reported in the guidelines. ${ }^{3}$ The sample size of females was only 117 , which was relatively small for subgroup analysis. Second, their study also included patients with metastasis, with $44(10.1 \%)$ patients of the whole population having metastasis before surgery. Meanwhile, Byun et al analyzed 2097 patients with nonmetastatic clearcell RCC who underwent surgery. ${ }^{16}$ They also reported that a high BMI is associated with greater recurrence-free survival or CSS rates among all patients and men, but not among women. Although their study had a large sample size, there were 1524 males and only 573 females, resulting in a male-to -female ratio as high as 2.6:1. This finding might attenuate any putative associations between sex, BMI, and RCC prognosis.

Our study has several advantages over the four studies mentioned above. ${ }^{10,16,17,22}$ First, we only included patients with nonmetastatic RCC (pathological T1-4N0M0) and excluded those with metastasis before surgery, because the presence of metastasis might influence the analysis of associations between sex, BMI, and survival outcomes in RCC. Second, our study included 414 males and 229 females, resulting in a male-to female ratio of 1.81:1, which is close to $1.5: 1$. Lastly, we included the majority of well-known accepted prognostic factors of nonmetastatic RCC, including age, nuclear grade, histological subtype, tumor necrosis, tumor size, and pathological stage. ${ }^{3}$

The obesity paradox has been observed in several studies, ${ }^{23}$ but its cause remains unclear. Our findings suggest that sex should be considered when evaluating the prognostic value of obesity in RCC prognosis. However, it is unclear why the relationship between obesity and RCC prognosis may be sex-specific. One hypothesis is that 
Table 8 Clear cell RCC patient characteristics*Statistically significant

\begin{tabular}{|c|c|c|c|c|}
\hline Variables & All $(n=562)$ & Male $(n=367)$ & Female $(n=195)$ & $P$-value \\
\hline Age ( $>65$ vs $\leq 65$ years) & $240 / 322$ & $160 / 207$ & $80 / 115$ & 0.558 \\
\hline ASA grade ( $\geq 3$ vs $<3$ ) & $40 / 522$ & $27 / 340$ & $13 / 182$ & 0.762 \\
\hline \multicolumn{5}{|l|}{$\mathrm{BMI}, \mathrm{Kg} / \mathrm{m}^{2}$} \\
\hline (3) Mean $\pm \mathrm{SD}, \mathrm{Kg} / \mathrm{m}^{2}$ & $23.5(2.9)$ & $23.6(2.8)$ & $22.5(3.0)$ & $<0.001 *$ \\
\hline (4) High vs normal BMI & $146 / 416$ & $110 / 257$ & $36 / 159$ & $0.003 *$ \\
\hline DM (yes vs no) & $218 / 425$ & $127 / 240$ & $66 / 129$ & 0.857 \\
\hline Hypertension (yes vs no) & $236 / 326$ & $164 / 203$ & $72 / 123$ & 0.076 \\
\hline Anemia (yes vs no) & $93 / 550$ & $43 / 324$ & $33 / 162$ & 0.086 \\
\hline Surgical approach & & & & 0.196 \\
\hline Partial nephrectomy & 118 & 83 & 35 & \\
\hline Radical nephrectomy & 444 & 284 & 160 & \\
\hline CKD stage & & & & 0.253 \\
\hline CKD I & 371 & 233 & 138 & \\
\hline CKD 2 & 153 & 111 & 42 & \\
\hline CKD 3 & 26 & 15 & 11 & \\
\hline CKD 4 & 3 & 2 & 1 & \\
\hline CKD 5 & 9 & 6 & 3 & \\
\hline Pathologic stage & & & & 0.153 \\
\hline $\mathrm{pTI}$ & 443 & 289 & 154 & \\
\hline pT2 & 65 & 37 & 28 & \\
\hline pT3 & 47 & 35 & 12 & \\
\hline pT4 & 7 & 6 & 1 & \\
\hline Fuhrman grade ( $\geq 3$ vs $<3$ ) & $125 / 437$ & $85 / 282$ & $40 / 155$ & 0.472 \\
\hline Tumor necrosis (Yes vs No) & $22 / 621$ & $13 / 354$ & $6 / 189$ & $0.77 \mid$ \\
\hline Tumor size $(\geq 7 \mathrm{vs}<7 \mathrm{~cm})$ & $97 / 465$ & $58 / 309$ & $39 / 156$ & 0.210 \\
\hline Follow-up duration, months, median (IQR) & $51.5(30.9-87.7)$ & $49.3(30.2-84.4)$ & $57.8(31.7-93.4)$ & 0.065 \\
\hline All -cause death, $n(\%)$ & $48(8.5 \%)$ & $35(9.5 \%)$ & $13(6.7 \%)$ & 0.247 \\
\hline Cancer-specific death, $n(\%)$ & $33(5.9 \%)$ & $20(5.4 \%)$ & $13(6.7 \%)$ & 0.559 \\
\hline Metastasis, $\mathrm{n}(\%)$ & $61(10.9 \%)$ & $45(12.3 \%)$ & $16(8.2 \%)$ & 0.141 \\
\hline
\end{tabular}

Abbreviations: BMI, body mass index; RCC, renal cell carcinoma; ASA, American Society of Anesthesiologists; DM, diabetes mellitus; CKD, chronic kidney disease; IQR, interquartile range.

changes in hormones and genetic expression, which are two sex-specific factors, may influence the magnitude of the prognostic role of obesity in RCC. A previous study revealed that the body weight of women would reach its maximum during menopause and their relative body fat and abdominal fatness would increase with advancing age. ${ }^{24}$ In our study, there was a trend toward an increased BMI with increasing age in females, although the relationship was not significant $(P=0.656)$. These physiological features are regulated by hormonal changes and may lead to significant differences in predicting the $\mathrm{RCC}$ prognosis according to BMI between men and women. Regarding to the genomic characteristics of RCC between men and women, Lucca et al reported that immune- or inflammation-associated genes are more likely to overexpress in males, while catabolic process-related genes tend to overexpress in females. ${ }^{25}$ Brannon et al performed a metaanalysis of studies on gene expression in clear cell RCC. In their study of 366 autosomal genes, they identified 326 (89.1\%) genes as differentially expressed between the 
Table 9 The significance of BMI for the prediction of OS, CSS, and MFS using multivariate analysis by sex among clear cell RCC patients

\begin{tabular}{|c|c|c|c|c|c|c|c|}
\hline \multirow[t]{2}{*}{ os } & \multicolumn{4}{|c|}{ BMI as categorical variable } & \multicolumn{3}{|c|}{ BMI as continuous variable } \\
\hline & & HR & $95 \% \mathrm{Cl}$ & $P$-value & HR & $95 \% \mathrm{Cl}$ & $P$-value \\
\hline All & High vs normal BMI & 0.320 & $0.112-0.918$ & $0.030 *$ & 0.877 & $0.760-1.011$ & $0.04 I *$ \\
\hline Men & High vs normal BMI & 0.158 & $0.037-0.683$ & $0.013^{*}$ & 0.798 & $0.663-0.961$ & $0.017^{*}$ \\
\hline Women & High vs normal BMI & 1.358 & $0.274-6.741$ & 0.708 & 1.023 & $0.823-|.27|$ & 0.837 \\
\hline \multirow[t]{2}{*}{ CSS } & \multicolumn{4}{|c|}{ BMI as categorical variable } & \multicolumn{3}{|c|}{ BMI as continuous variable } \\
\hline & & HR & $95 \% \mathrm{Cl}$ & $P$-value & HR & $95 \% \mathrm{Cl}$ & $P$-value \\
\hline All & High vs normal BMI & 0.325 & $0.094-1.127$ & $0.046 *$ & 0.885 & $0.747-1.048$ & $0.045 *$ \\
\hline Men & High vs normal BMI & 0.104 & $0.013-0.867$ & $0.036 *$ & 0.756 & $0.586-0.977$ & $0.032 *$ \\
\hline Women & High vs normal BMI & 1.358 & $0.274-6.741$ & 0.708 & 1.023 & $0.823-|.27|$ & 0.837 \\
\hline \multirow[t]{2}{*}{ MFS } & \multicolumn{4}{|c|}{ BMI as categorical variable } & \multicolumn{3}{|c|}{ BMI as continuous variable } \\
\hline & & HR & $95 \% \mathrm{Cl}$ & $P$-value & HR & $95 \% \mathrm{Cl}$ & $P$-value \\
\hline All & High vs normal BMI & 0.312 & $0.130-0.749$ & $0.009 *$ & 0.913 & $0.811-1.029$ & $0.005^{*}$ \\
\hline Men & High vs normal BMI & 0.229 & $0.078-0.668$ & $0.007^{*}$ & 0.869 & $0.745-1.013$ & $0.003 *$ \\
\hline Women & High vs normal BMI & 0.865 & $0.189-3.956$ & 0.851 & 0.956 & $0.777-1.177$ & 0.675 \\
\hline
\end{tabular}

Note: *Statistically significant.

Abbreviations: BMI, body mass index; CSS; cancer-specific survival; MFS, metastasis-free survival; RCC, renal cell carcinoma; OS, overall survival.

sexes. Furthermore, some of these gene participate in important biological processes, including DNA repair (PARP8 and ERCC5), cell signaling (MAPKSP1, SPAG1, etc.) and cell motility (VCAN and CYR61) ${ }^{26}$ A previous study also analyzed three large-scale clear cell RCC mutation sequencing projects. Their results revealed that mutation of the BAP1 gene was significantly associated with poorer OS in the whole population and among females, but not among males. Furthermore, they concluded that the combination of sex and mutation of a specific gene, such as BAP1, may be associated with OS in RCC patients. ${ }^{27}$

Our study has several limitations. First, it has a retrospective design and was conducted in a single institution, which might have led to selection bias. Nevertheless, our department is the largest urological center with the largest sample size for RCC patients in the south of Zhejiang Province; therefore, our data were representative and reliable. Second, we were unable to include some potential predictors, such as smoking history and nutritional status, due to lack of patient information. The antecedent weight loss, which might have influenced the outcomes, was also not reported. However, we had included the majority of well-known accepted prognostic factors of nonmetastatic RCC. Lastly, we were also unable to obtain information on waist circumference, waist-to-hip ratio, and visceral adiposity that could further improve the understanding of the prognostic role of obesity in survival outcomes in RCC patients. Nevertheless, BMI is the most widely used index for obesity in clinical practice. Thus, further prospective studies and basic researches are required to investigate the sex-dependent prognostic value and mechanisms of BMI in RCC patients.

\section{Conclusion}

Our study showed that a high BMI was a favorable prognostic factor in patients with nonmetastatic RCC who underwent nephrectomy. However, when the patients were stratified according to sex, BMI was significantly associated with OS, CSS, and MFS only among men, and not among women. The same findings were observed among patients with clear cell RCC. Our results suggest that sex may influence the relationship between obesity and prognosis of nonmetastatic RCC.

\section{Abbreviation list}

RCC, renal cell carcinoma; BMI, body mass index; OS, overall survival; MFS, metastasis-free survival; CSS, cancer-specific survival; CKD, chronic kidney disease; DM, diabetes mellitus. 


\section{Ethics approval and informed consent}

This study was approved by the ethics committee of the First Affiliated Hospital of Wenzhou Medical University (Wenzhou, China). The study protocol is in accordance with the Declaration of Helsinki. All patients' informed consent from telephone interview had been obtained before their participation in this study, although none of them came to our center to give written informed consent. Furthermore, we stated that all data from patients was anonymized or maintained with confidentiality. The consent process has been approved by the ethics committee of the First Affiliated Hospital of Wenzhou Medical University (Wenzhou, China).

\section{Acknowledgments}

This study was supported by the 2018 Zhejiang medical and health science and technology program(2018KY930), and the 2017 Lishui science and technology planning program (2017GYX14). The authors thank Editage for English language editing.

\section{Author contributions}

Xiaomin Gao conceived and designed the study, Yangqin Zheng, Lianmin Bao, and Jingfeng Chen acquired the data, Yue Pan analyzed and interpreted the data, and Lianguo Chen and Xiaomin Gao drafted the manuscript. All authors contributed to data analysis, drafting and revising the article, gave final approval of the version to be published, and agree to be accountable for all aspects of the work.

\section{Disclosure}

The authors report no conflicts of interest in this work.

\section{References}

1. Siegel RL, Miller KD, Jemal A. Cancer Statistics, 2017. CA Cancer $J$ Clin. 2017;67(1):7-30. doi:10.3322/caac.21387

2. Capitanio U, Montorsi F. Renal cancer. Lancet. 2016;387 (10021):894-906. doi:10.1016/S0140-6736(15)00046-X

3. Ljungberg B, Bensalah K, Canfield S, et al. EAU guidelines on renal cell carcinoma: 2014 update. Eur Urol. 2015;67(5):913-924. doi:10.1016/j.eururo.2015.01.005

4. Chiong E, Tay MH, Tan MH, et al. Management of kidney cancer in Asia: resource-stratified guidelines from the Asian Oncology Summit 2012. Lancet Oncol. 2012;13(11):e482-e491. doi:10.1016/S14702045(12)70433-3

5. Mathew A, Devesa SS, Fraumeni JF Jr., Chow WH. Global increases in kidney cancer incidence, 1973-1992. Eur J Cancer Prev. 2002;11 (2):171-178. doi:10.1097/00008469-200204000-00010
6. Chow WH, Dong LM, Devesa SS. Epidemiology and risk factors for kidney cancer. Nat Rev Urol. 2010;7(5):245-257. doi:10.1038/ nrurol.2010.46

7. Adams KF, Leitzmann MF, Albanes D, et al. Body size and renal cell cancer incidence in a large US cohort study. Am J Epidemiol. 2008;168(3):268-277. doi:10.1093/aje/kwn122

8. Hakimi AA, Furberg H, Zabor EC, et al. An epidemiologic and genomic investigation into the obesity paradox in renal cell carcinoma. $J$ Natl Cancer Inst. 2013;105(24):1862-1870. doi:10.1093/jnci/djt310

9. Ather MH, Nazim SM. Impact of Charlson's comorbidity index on overall survival following tumor nephrectomy for renal cell carcinoma. Int Urol Nephrol. 2010;42(2):299-303. doi:10.1007/s11255009-9636-8

10. Donat SM, Salzhauer EW, Mitra N, Yanke BV, Snyder ME, Russo P. Impact of body mass index on survival of patients with surgically treated renal cell carcinoma. J Urol. 2006;175(1):46-52. doi:10.1016/ S0022-5347(05)00054-6

11. Steffens S, Ringe KI, Schroeer K, et al. Does overweight influence the prognosis of renal cell carcinoma? Results of a multicenter study. Int J Urol. 2013;20(6):585-592. doi:10.1111/iju.12000

12. Komura K, Inamoto T, Black PC, et al. Prognostic significance of body mass index in Asian patients with localized renal cell carcinoma. Nutr Cancer. 2011;63(6):908-915. doi:10.1080/0163 5581.2011.594207

13. Bagheri M, Speakman JR, Shemirani F, Djafarian K. Renal cell carcinoma survival and body mass index: a dose-response meta-analysis reveals another potential paradox within a paradox. Int J Obes (Lond). 2016;40(12):1817-1822. doi:10.1038/ijo.2016.171

14. Ito R, Narita S, Huang M, et al. The impact of obesity and adiponectin signaling in patients with renal cell carcinoma: a potential mechanism for the "obesity paradox". PLoS One. 2017;12(2): e0171615. doi:10.1371/journal.pone.0171615

15. Shen T, Shu XO, Xiang YB, et al. Association of hypertension and obesity with renal cell carcinoma risk: a report from the Shanghai men's and women's health studies. Cancer Causes Control. 2015;26 (8):1173-1180. doi:10.1007/s10552-015-0611-7

16. Byun SS, Hwang EC, Kang SH, et al. Sex-specific prognostic significance of obesity in nonmetastatic clear-cell renal-cell carcinoma in Korea: a large multicenter cohort analysis. Clin Genitourin Cancer. 2017;16(1):e173-e179. doi:10.1016/j. clgc.2017.08.015

17. Ohno Y, Nakashima J, Nakagami Y, et al. Sex and the clinical value of body mass index in patients with clear cell renal cell carcinoma. $\mathrm{Br}$ J Cancer. 2013;109(7):1899-1903. doi:10.1038/bjc.2013.512

18. Razak F, Anand SS, Shannon H, et al. Defining obesity cut points in a multiethnic population. Circulation. 2007;115(16):2111-2118. doi:10.1161/CIRCULATIONAHA.106.635011

19. Park SK, Ryoo JH, Oh CM, et al. Effect of overweight and obesity (Defined by Asian-specific cutoff criteria) on left ventricular diastolic function and structure in a General Korean population. Circ $j$. 2016;80(12):2489-2495. doi:10.1253/circj.CJ-16-0625

20. World Health Organization, International Obesity Task Force. The Asian-Pacific Perspective: Redefining Obesity and Its Treatment. Geneva, Switzerland: WHO Western Pacific Region; 2000.

21. Choi Y, Park B, Jeong BC, et al. Body mass index and survival in patients with renal cell carcinoma: a clinical-based cohort and meta-analysis. Int $J$ Cancer. 2013;132(3):625-634. doi:10.1002/ ijc. 27639

22. Reeves GK, Pirie K, Beral V, Green J, Spencer E, Bull D. Cancer incidence and mortality in relation to body mass index in the million women study: cohort study. Bmj. 2007;335(7630):1134. doi:10.1136/ bmj.39367.495995.AE

23. Gurunathan U, Myles PS. Limitations of body mass index as an obesity measure of perioperative risk. $B r \quad J$ Anaesth. 2016;116 (3):319-321. doi:10.1093/bja/aev541 
24. Astrup A. Physical activity and weight gain and fat distribution changes with menopause: current evidence and research issues. Med Sci Sports Exerc. 1999;31(11 Suppl):S564-S567.

25. Lucca I, Klatte T, Fajkovic H, de Martino M, Shariat SF. Gender differences in incidence and outcomes of urothelial and kidney cancer. Nat Rev Urol. 2015;12(10):585-592. doi:10.1038/nrurol.2015.232

26. Haake SM, Hacker KE, Pruthi RS, Wallen EM, Nielsen ME, Rathmell WK. Meta-analysis of clear cell renal cell carcinoma gene expression defines a variant subgroup and identifies gender influences on tumor biology.\%A Brannon AR. Eur Urol. 2012;61(2):258-268. doi:10.1016/j.eururo.2011.10.007
27. Linehan WM. Gender specific mutation incidence and survival associations in clear cell renal cell Carcinoma (CCRCC).\%A ricketts CJ. PLoS One. 2015;10(10):e0140257. doi:10.1371/journal. pone. 0140257 


\section{Supplementary materials}

Table SI Univariate analysis of variables for the prediction of overall survival in all patients

\begin{tabular}{|c|c|c|c|c|c|c|}
\hline \multirow[t]{2}{*}{ Variables } & \multicolumn{3}{|c|}{ BMI as categorical variable } & \multicolumn{3}{|c|}{ BMI as continuous variable } \\
\hline & HR & $95 \% \mathrm{Cl}$ & $P$-value & HR & $95 \% \mathrm{Cl}$ & $P$-value \\
\hline Age ( $>65$ vs $\leq 65$ years) & 4.597 & $2.428-8.705$ & $<0.001 *$ & 6.017 & $3.115-11.620$ & $<0.00 I^{*}$ \\
\hline ASA grade ( $\geq 3$ vs $<3$ ) & 3.731 & $1.963-7.092$ & $<0.00 I^{*}$ & 3.873 & $1.846-8.125$ & $<0.00 I^{*}$ \\
\hline Gender (men vs women) & 1.807 & $0.988-3.307$ & 0.055 & 1.780 & $0.952-3.329$ & 0.071 \\
\hline $\begin{array}{l}\text { BMI, } \mathrm{Kg} / \mathrm{m}^{2} \\
\text { (I) Category: } \geq 25 \text { vs }<25 \\
\text { (2) Continuous }\end{array}$ & $0.28 \mathrm{I}$ & $0.112-0.704$ & $0.007 *$ & 0.837 & $0.745-0.939$ & $0.002^{*}$ \\
\hline DM (yes vs no) & $1.09 \mid$ & $0.628-1.895$ & 0.756 & 0.972 & $0.546-|.73|$ & 0.924 \\
\hline Hypertension (yes vs no) & 1.204 & $0.712-2.034$ & 0.488 & 1.080 & $0.624-1.868$ & 0.784 \\
\hline Anemia (yes vs no) & 3.801 & $2.223-6.500$ & $<0.00 I^{*}$ & 4.559 & $2.532-8.210$ & $<0.00 I^{*}$ \\
\hline Surgical approach (partial vs radical) & 0.435 & $0.173-1.091$ & 0.076 & 0.324 & $0.127-0.828$ & $0.019 *$ \\
\hline $\begin{array}{l}\text { CKD stage } \\
\text { CKD I } \\
\text { CKD 2-3 vs CKD I } \\
\text { CKD 4-5 vs CKD I }\end{array}$ & $\begin{array}{l}1.000 \\
2.369 \\
7.691\end{array}$ & $\begin{array}{l}\text { Reference } \\
\text { I.374-4.085 } \\
2.664-22.207\end{array}$ & $\begin{array}{l}1.000 \\
0.002 * \\
<0.001 *\end{array}$ & $\begin{array}{l}1.000 \\
2.746 \\
6.667\end{array}$ & $\begin{array}{l}\text { Reference } \\
1.554-4.852 \\
1.948-22.820\end{array}$ & $\begin{array}{l}1.000 \\
0.00 I^{*} \\
0.003^{*}\end{array}$ \\
\hline $\begin{array}{l}\text { Pathologic stage } \\
\qquad \text { PTI } \\
\text { PT2 vs PTI } \\
\text { PT3 vs PTI } \\
\text { PT4 vs PTI }\end{array}$ & $\begin{array}{l}1.000 \\
2.810 \\
3.762 \\
5.906\end{array}$ & $\begin{array}{l}\text { Reference } \\
1.469-5.375 \\
1.885-7.507 \\
1.409-24.746\end{array}$ & $\begin{array}{l}1.000 \\
0.002 * \\
<0.001 * \\
0.015 *\end{array}$ & $\begin{array}{l}1.000 \\
3.165 \\
3.321 \\
5.032\end{array}$ & $\begin{array}{l}\text { Reference } \\
1.572-6.373 \\
1.573-7.011 \\
0.975-25.970\end{array}$ & $\begin{array}{l}1.000 \\
0.001^{*} \\
0.002^{*} \\
0.014^{*}\end{array}$ \\
\hline Fuhrman grade ( $\geq 3$ vs $<3$ ) & 2.753 & I.635-4.634 & $<0.001 *$ & 3.427 & $1.970-5.961$ & $<0.00 I^{*}$ \\
\hline Histologic subtype (Clear cell vs non-clear cell) & 1.418 & $0.695-2.892$ & 0.337 & 1.339 & $0.630-2.843$ & 0.448 \\
\hline Tumor necrosis (Yes vs No) & 2.388 & $0.863-6.607$ & 0.094 & 2.382 & $0.778-7.295$ & 0.129 \\
\hline Tumor size ( $\geq 7$ vs $<7$ ) & 2.733 & $1.585-4.713$ & $<0.00 I^{*}$ & 2.902 & $1.613-5.224$ & $<0.00 I^{*}$ \\
\hline
\end{tabular}

Note: *Statistically significant.

Abbreviations: ASA, American Society of Anesthesiologists; BMI, body mass index; CKD, chronic kidney disease; DM, diabetes mellitus. 
Table S2 Univariate analysis of variables for the prediction of cancer-specific survival in all patients

\begin{tabular}{|c|c|c|c|c|c|c|}
\hline \multirow[t]{2}{*}{ Variables } & \multicolumn{3}{|c|}{ BMI as categorical variable } & \multicolumn{3}{|c|}{ BMI as continuous variable } \\
\hline & HR & $95 \% \mathrm{Cl}$ & $P$-value & HR & $95 \% \mathrm{Cl}$ & $P$-value \\
\hline Age ( $>65$ vs $\leq 65$ years) & 4.196 & $1.990-8.845$ & $<0.001 *$ & 5.056 & $2.358-10.837$ & $<0.00 I^{*}$ \\
\hline ASA grade ( $\geq 3$ vs $<3$ ) & 3.773 & $1.733-8.215$ & $0.00 I^{*}$ & 4.072 & $1.745-9.499$ & $0.00 I^{*}$ \\
\hline Gender (men vs women) & 1.069 & $0.555-2.058$ & 0.842 & 0.987 & $0.502-1.939$ & 0.970 \\
\hline $\begin{array}{l}\text { BMI, } \mathrm{Kg} / \mathrm{m}^{2} \\
\text { (I) Category: } \geq 25 \text { vs }<25 \\
\text { (2) Continuous }\end{array}$ & 0.333 & $0.118-0.938$ & $0.037^{*}$ & 0.843 & $0.735-0.967$ & $0.014^{*}$ \\
\hline DM (yes vs no) & 0.851 & $0.423-1.710$ & 0.650 & 0.753 & $0.368-1.544$ & 0.439 \\
\hline Hypertension (yes vs no) & 1.624 & $0.865-3.049$ & 0.131 & 1.480 & $0.774-2.831$ & 0.236 \\
\hline Anemia (yes vs no) & 3.297 & $1.713-6.345$ & $<0.00 I^{*}$ & 3.722 & I.856-7.462 & $<0.00 I^{*}$ \\
\hline Surgical approach (partial vs radical) & 0.372 & $0.114-1.211$ & 0.101 & 0.287 & $0.087-0.946$ & $0.040^{*}$ \\
\hline $\begin{array}{l}\text { CKD stage } \\
\text { CKD I } \\
\text { CKD 2-3 vs CKD । } \\
\text { CKD 4-5 vs CKD । }\end{array}$ & $\begin{array}{l}1.000 \\
2.789 \\
2.866\end{array}$ & $\begin{array}{l}\text { Reference } \\
1.463-5.318 \\
0.380-21.634\end{array}$ & $\begin{array}{l}1.000 \\
\mathbf{0 . 0 0 2 *} \\
0.307\end{array}$ & $\begin{array}{l}1.000 \\
3.066 \\
1.962\end{array}$ & $\begin{array}{l}\text { Reference } \\
1.573-5.974 \\
0.242-15.929\end{array}$ & $\begin{array}{l}1.000 \\
0.001 * \\
0.528\end{array}$ \\
\hline $\begin{array}{l}\text { Pathologic stage } \\
\text { PTI } \\
\text { PT2 vs PTI } \\
\text { PT3 vs PTI } \\
\text { PT4 vs PTI }\end{array}$ & $\begin{array}{l}1.000 \\
3.714 \\
5.419 \\
10.264\end{array}$ & $\begin{array}{l}\text { Reference } \\
\text { I.7I2-8.055 } \\
2.429-12.087 \\
2.372-44.4||\end{array}$ & $\begin{array}{l}1.000 \\
0.001^{*} \\
<0.00 I^{*} \\
0.002^{*}\end{array}$ & $\begin{array}{l}1.000 \\
4.111 \\
4.625 \\
8.907\end{array}$ & $\begin{array}{l}\text { Reference } \\
1.819-9.290 \\
1.977-10.818 \\
1.680-47.225\end{array}$ & $\begin{array}{l}1.000 \\
0.001 * \\
<0.001 * \\
0.010^{*}\end{array}$ \\
\hline Fuhrman grade ( $\geq 3$ vs $<3$ ) & 3.479 & I.844-6.562 & $<0.001 *$ & 4.172 & $2.156-8.073$ & $<0.00 I^{*}$ \\
\hline Histologic subtype (Clear cell vs non-clear cell) & 1.377 & $0.577-3.289$ & 0.471 & 1.282 & $0.520-3.163$ & 0.589 \\
\hline Tumor necrosis (yes vsno) & 3.506 & $1.245-9.873$ & $0.018^{*}$ & 3.721 & I.195-II.585 & $0.023^{*}$ \\
\hline Tumor size ( $\geq 7$ vs $<7$ ) & 4.282 & $2.281-8.039$ & $<0.00 I^{*}$ & 4.650 & $2.387-9.060$ & $<0.00 I^{*}$ \\
\hline
\end{tabular}

Note: *Statistically significant.

Abbreviations: ASA, American Society of Anesthesiologists; BMI, body mass index; CKD, chronic kidney disease; DM, diabetes mellitus. 
Table S3 Univariate analysis of variables for the prediction of metastasis-free survival in all patients

\begin{tabular}{|c|c|c|c|c|c|c|}
\hline \multirow[t]{2}{*}{ Variables } & \multicolumn{3}{|c|}{ BMI as categorical variable } & \multicolumn{3}{|c|}{ BMI as continuous variable } \\
\hline & HR & $95 \% \mathrm{Cl}$ & $P$-value & HR & $95 \% \mathrm{Cl}$ & $P$-value \\
\hline Age ( $>65$ vs $\leq 65$ years) & 2.864 & $1.730-4.74 \mid$ & $<0.001 *$ & 3.537 & $2.081-6.012$ & $<0.00 I^{*}$ \\
\hline ASA grade ( $\geq 3$ vs $<3$ ) & 2.319 & I.188-4.530 & $0.014^{*}$ & 1.871 & $1.057-3.311$ & $0.032 *$ \\
\hline Gender (men vs women) & 1.924 & I.II5-3.322 & 0.019 & 1.780 & $0.952-3.329$ & 0.071 \\
\hline $\begin{array}{l}\text { BMI, } \mathrm{Kg} / \mathrm{m}^{2} \\
\text { (I) Category: } \geq 25 \text { vs }<25 \\
\text { (2) Continuous }\end{array}$ & 0.316 & $0.145-0.690$ & $0.004^{*}$ & 0.300 & $0.134-0.668$ & $0.003 *$ \\
\hline DM (yes vs no) & 0.833 & $0.496-1.399$ & 0.490 & 0.741 & $0.429-1.278$ & 0.281 \\
\hline Hypertension (yes vs no) & 1.580 & $0.991-2.520$ & 0.055 & 1.475 & $0.900-2.418$ & 0.123 \\
\hline Anemia (yes vs no) & 2.711 & I.638-4.485 & $<0.00 I^{*}$ & 2.711 & $1.638-4.485$ & $<0.00 I^{*}$ \\
\hline Surgical approach (partial vs radical) & 0.452 & $0.207-0.988$ & 0.047 & 0.365 & $0.163-0.815$ & $0.014^{*}$ \\
\hline $\begin{array}{l}\text { CKD stage } \\
\text { CKD I } \\
\text { CKD 2-3 vs CKD I } \\
\text { CKD 4-5 vs CKD I }\end{array}$ & $\begin{array}{l}1.000 \\
2.148 \\
7.691\end{array}$ & $\begin{array}{l}\text { Reference } \\
\text { I.324-3.484 } \\
2.664-22.207\end{array}$ & $\begin{array}{l}1.000 \\
0.002 * \\
<0.001 *\end{array}$ & $\begin{array}{l}1.000 \\
2.436 \\
6.806\end{array}$ & $\begin{array}{l}\text { Reference } \\
1.455-4.077 \\
2.153-21.518\end{array}$ & $\begin{array}{l}1.000 \\
0.001 * \\
0.001 *\end{array}$ \\
\hline $\begin{array}{l}\text { Pathologic stage } \\
\qquad \text { PTI } \\
\text { PT2 vs PTI } \\
\text { PT3 vs PTI } \\
\text { PT4 vs PTI }\end{array}$ & $\begin{array}{l}1.000 \\
2.692 \\
3.115 \\
4.459\end{array}$ & $\begin{array}{l}\text { Reference } \\
\text { I.509-4.803 } \\
1.635-5.936 \\
1.076-18.483\end{array}$ & $\begin{array}{l}1.000 \\
0.001 * \\
0.001 * \\
0.009 *\end{array}$ & $\begin{array}{l}1.000 \\
3.029 \\
2.736 \\
3.724\end{array}$ & $\begin{array}{l}\text { Reference } \\
\text { I.600-5.735 } \\
\text { I.348-5.55। } \\
0.728-|9.04|\end{array}$ & $\begin{array}{l}1.000 \\
0.001^{*} \\
0.005^{*} \\
0.014^{*}\end{array}$ \\
\hline Fuhrman grade ( $\geq 3$ vs $<3$ ) & 2.371 & $1.485-3.785$ & $<0.001 *$ & 3.427 & $1.970-5.961$ & $<0.00 I^{*}$ \\
\hline Histologic subtype (clear cell vs non-clear cell) & 1.240 & $0.635-2.422$ & 0.528 & 1.339 & $0.630-2.843$ & 0.448 \\
\hline Tumor necrosis (yes vs no) & 3.210 & $1.390-7.417$ & $0.006 *$ & 2.382 & $0.778-7.295$ & 0.129 \\
\hline Tumor size ( $\geq 7$ vs $<7$ ) & 2.604 & I.592-4.260 & $<0.00 I^{*}$ & 2.902 & $1.613-5.224$ & $<0.001 *$ \\
\hline
\end{tabular}

Note: *Statistically significant.

Abbreviations: ASA, American Society of Anesthesiologists; BMI, body mass index; CKD, chronic kidney disease; DM, diabetes mellitus.

\section{Publish your work in this journal}

Cancer Management and Research is an international, peer-reviewed open access journal focusing on cancer research and the optimal use of preventative and integrated treatment interventions to achieve improved outcomes, enhanced survival and quality of life for the cancer patient.
The manuscript management system is completely online and includes a very quick and fair peer-review system, which is all easy to use. Visit http://www.dovepress.com/testimonials.php to read real quotes from published authors. 